\title{
Melanesian Tribes vs. Polynesian Chiefdoms: Recent Archaeological Assessment of a Classic Model of Sociopolitical Types in Oceania
}

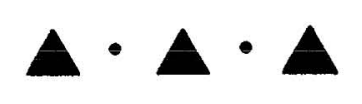

CHRISTOPHE SAND

EVER SINCE THEIR DISCOVERy OF THE PACIFIC SOCIETy IsLANDs, Europeans have identified cultural differences between the populations living in the different islands of the great ocean (Beaglehole 1974). Arriving for the first time in Tahiti in 1769, Bougainville thought he had found the "nouvelle cythère," prompting generations of writers to describe Polynesia as a "Paradise on Earth." In contrast, frequent violent encounters with darker-skinned populations in the Western Pacific (Bonnemaison 1984; Spriggs 1997) led to a contrasting perception of "savagery" for the societies that occupied the region named "Melanesia" by Dumont d'Urville (Boulay 2000). This dichotomized schema of indigenous oceanic cultures, with a divide between Melanesian and Polynesian societies, has been maintained in much of the literature on the Pacific. The classic work in this genre was that of Marshall Sahlins, concerning Melanesian Big-Men and Polynesian chiefs. Basing his synthesis on ethnographic data, Sahlins (1963) differentiated the tribal societies of Melanesia, with their supposed low level of hierarchical differentiation in small territorial units, from the large, complex multilevel Polynesian polities. To be sure, anthropologists and ethnohistorians have themselves critiqued Sahlins' (1963) model as one that was overly simplifying (e.g., Douglas 1979; Thomas 1997); nonetheless, aspects of the model persist in current theoretical conceptions in Oceanic anthropology.

This paper-which was written to stimulate discussion at the Eastern Polynesia Mo'orea conference - aims to draw attention to recent archaeological fieldwork carried out in several parts of Island Melanesia (see Fig. 1), which has begun to yield a rather different picture of late prehistory for this part of the Pacific. ${ }^{1}$ This is by no means a complete review, a task which must be left to another occasion. In order to facilitate comparison between the data from Island Melanesia to Polynesia, my presentation is divided into six major topics. These demonstrate that the cultural distinction, first imposed by the early European explorers, between the complex "nearly civilized" Polynesian societies and the simpler "savage" Mela-

Christophe Sand is in the Département Archéologie, Service des Musées, Nouméa, New Caledonia. Asian Perspectives, Vol. 41, No. 2 (C) 2002 by University of Hawai'i Press. 


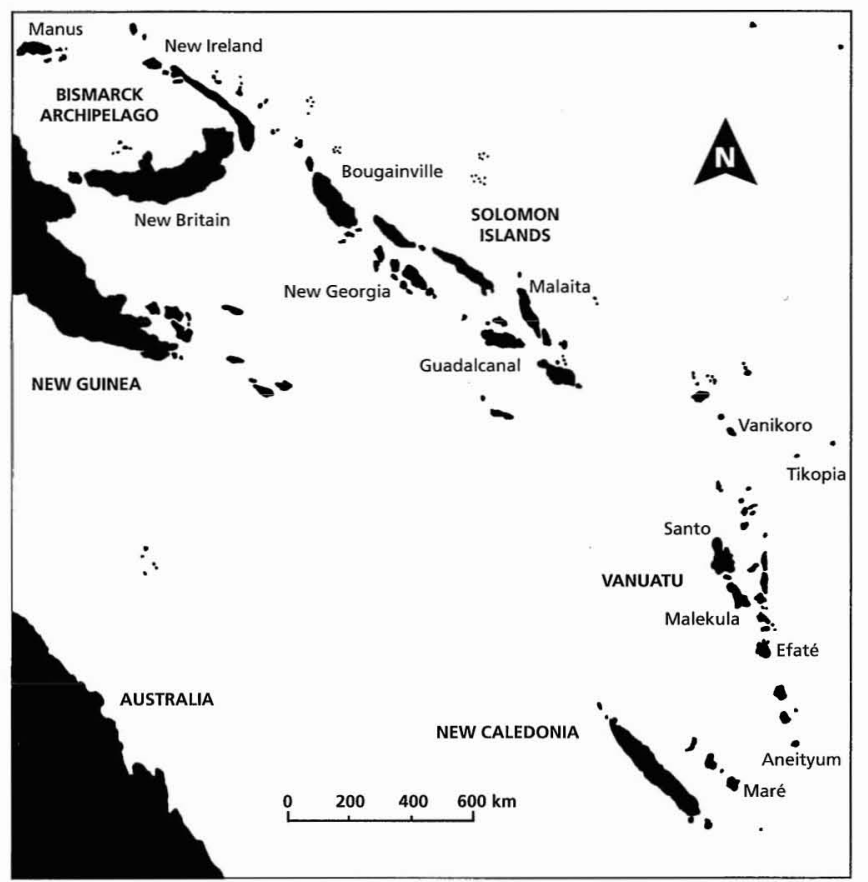

Fig. 1. Location of the Melanesian archipelagoes in the southwestern Pacific.

nesian tribes, and later incorporated into anthropological models (see Thomas 1989), is not supported by the archaeological record.

Numerous accounts, both of nineteenth-century explorers and of early twentieth-century ethnologists described in detail the functioning of former Polynesian chiefdoms (see Goldman 1970; Sahlins 1958 for summary accounts). Archaeological studies have concentrated on precontact Polynesian settlement patterns and monumental architecture, analyzing in detail the ethnohistoric data gathered by the early explorers (Kirch 1984a). The abundant remains readily visible on the surface of Polynesian islands led to countless survey and typological studies of architectural elements: religious marae, family and collective house mounds, fortifications, and so forth (e.g., Bellwood 1979). Using such field data, recent works have refined the different types of Polynesian chiefdoms that developed in West and East Polynesia during the final centuries prior to European contact (e.g., Kirch 2000).

The classic model of a Melanesian Big-Man society, on the other hand, has been defined as one in which the leaders build on long-term family and group involvement, to achieve wealth and surplus (social) production, allowing the leader to pass different social grades (e.g., Godelier 1982; Lemonier 1990; Sahlins 1963). Political positions are not hereditary, and community level decisionmaking is supposed to dominate the tribal political system. No large-scale territorial units were presumed to have been present, and the control of the leaders over only part of the social group meant that no large-scale working force could be assembled for large constructions of any kind. 


\section{ARCHAEOLOGICAL EVIDENCE FOR MELANESIAN COMPLEXITY}

\section{Habitation Sites and Settlement Patterns}

Green (1991) has accurately pointed out the problems of using the generic term "Melanesia" as a significant cultural category, as it encompasses both Northern Melanesia (or what Green calls Near Oceania), settled more than 30,000 years ago, and Southern Melanesia (Vanuatu, the Loyalty Islands, New Caledonia, and Fiji), which as part of Remote Oceania was settled only 3000 years ago by Austronesian speakers. In this paper, I nevertheless use the term "Island Melanesia" in its broadest sense, as examples are drawn from the different archipelagoes of this geographical region which spans the Bismarck Archipelago to New Caledonia and Fiji. The hypothesis that former complex Island Melanesian societies, as in Polynesia, constituted chiefdom systems can be tested through several different sets of archaeological data. The first consists of habitation sites, analyzed with a settlement pattern approach. Although settlements were dispersed over the New Caledonian landscape, habitation sites comprised-for the Main Island (Grande Terre) of New Caledonia-clusters of mostly rounded house platforms, ranging from fewer than 10 to more than 100 structures per site (Sand 1997). These platforms were organized, in the major sites, to reproduce a rigid social hierarchy (see Fig. 2). A central alley was surrounded by parallel rows of habitation mounds, with the largest platform at the head of the alley and at the highest point, reserved for the house of the "great brother" (Boulay 1990). Commoners were not allowed to pass a certain point of the central alley, and some were never allowed to go into the main house. Some of these large house platforms are huge, with heights over $2.5 \mathrm{~m}$ and a diameter sometimes exceeding $20 \mathrm{~m}$. Such constructions would seem to imply a large building force and an effort to visibly indicate social differentiation and prestige (Sand 1995).

In northern Vanuatu, preliminary surveys have likewise shown the existence, in steep valleys of Pentecost and Maevo for example, of high stone-faced house platforms, with massive boulders used in their construction (Coiffier 1988); their

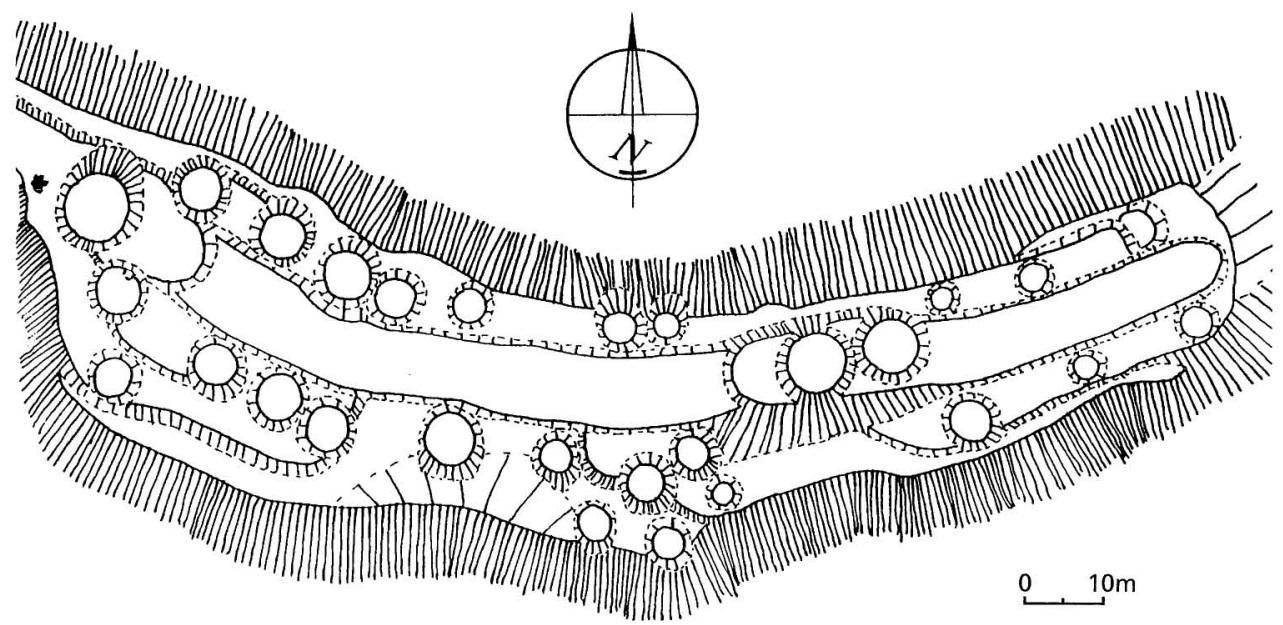

Fig. 2. Example of a former structured habitation site in central Grande Terre of New Caledonia. 
size can be compared to some of the better-known "megalithic" Marquesan sites of Eastern Polynesia (Ottino 1990). In the Loyalty Islands and Ile des Pins, where the uplifted coral environment did not lend itself to raised house platforms, the land area where the household of the "chief" was constructed was surrounded by a wooden palisade, forming something like a fenced enclosure (Guiart 1963; Lambert 1900). Commoners were not allowed to pass this fence, and complex symbolic divisions existed inside the area, with burial of sacred objects in strategic localities.

\section{Religious Sites}

Recent study of sacred and religious sites in some Melanesian islands is also starting to demonstrate previously unsuspected complexity. Multidisciplinary work undertaken in the Roviana lagoon region of the western Solomons, for example, has shown the existence of complex shrines, some in the form of large stone-faced platforms, with diverse uses as sites for prayers to ancestors, fishing shrines, or war shrines (Sheppard et al. 2000). These religious sites are distributed in the settlements in patterned ways that are as meaningful as sets of marae in East Polynesian contexts (e.g., Sinoto 1996). In Vanuatu, some sacred or religious sites such as Vao Island (northeast Malekula) are truly monumental, with large stone-faced platforms, the use of high monoliths weighing several tons, or the burial of major ancestors in large burial platforms (Burenhult 1994). The naga ceremonial sites of Fiji (Fig. 3) are another example of monumental Melanesian ritual constructions (Parke 1987:143-146). Once again, the functions of these sites and access to them was strictly codified.

\section{Horticultural Intensification}

The existence of former complex chiefdoms in Island Melanesia is perhaps best demonstrated by the scale of intensive horticultural sites. The most complex development of taro pondfield terraces anywhere in the Pacific occurred not in Hawai'i, but on the Grande Terre of New Caledonia (Barrau 1965; Kirch 1994). In some areas of this large island, the hillslope terraces cover hundreds of hectares (Fig. 4), with as many as 20 main irrigation channels, constructed on slopes as steep as 70 degrees (Sand 1994). In some steep-walled valleys, these stone-faced terraces are up to $3 \mathrm{~m}$ high, providing cultivation spaces sometimes less than $1 \mathrm{~m}$ wide (Sand 1999a). The labor force needed to build-and even more, to maintain-those irrigated fields could not have been assembled in small-scale, autonomous, and rival tribal systems.

Terracing and mounding systems on the river flats, like those found in much of Polynesia (Kirch 1985), are also present in Vanuatu and the Solomons (Bonnemaison 1974; Spriggs 1981, 1997), not to mention New Caledonia (Sand 2000). In some as yet poorly surveyed islands of Vanuatu such as Gaua in the Banks, the landscape is covered with stone walls, mostly for garden divisions; hundreds of kilometers of walls cross this island (Kaufman, pers. comm. 2000). A recent study on Manus, in the Bismarck archipelago, has shown a similar kind of pattern (McEldowney 1995). 


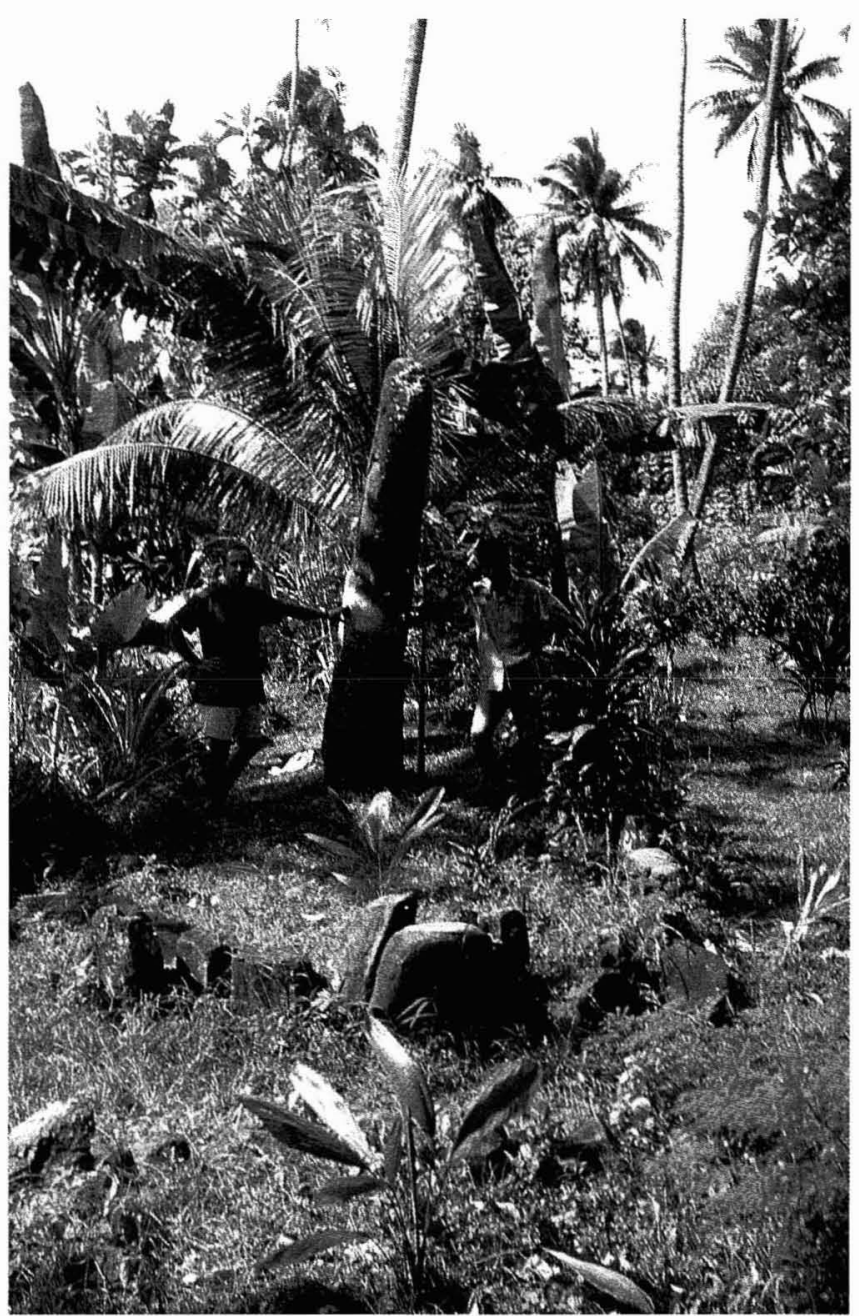

Fig. 3. A naga ceremonial site of eastern Fiji.

\section{Fortifications}

The last category of archaeological site relevant to testing the long-standing hypothesis of Polynesian vs. Melanesian complexity, is that of fortifications. Leaving aside that "archipelago of forts" which constitutes Fiji (e.g., Best 1993; Parry 1984), fortified places have begun to be identified in the Melanesian "croissant." In the Solomons, the Sheppard and Walter team have mapped a classic ridge-top fort in the Roviana lagoon, with different spatial areas (Sheppard et al. 2000: Fig. 5). Another type of monumental fort has been found on Mare in the Loyalty Islands (Fig. 5), with walls $500 \mathrm{~m}$ long, up to $10 \mathrm{~m}$ wide, and $4 \mathrm{~m}$ high, utilizing fossil coral blocks sometimes over $2.5 \mathrm{~m}$ long (Sand 1996). Once again, these types of sites could not have been constructed with small groups of people in an autonomous. tribal polity. 


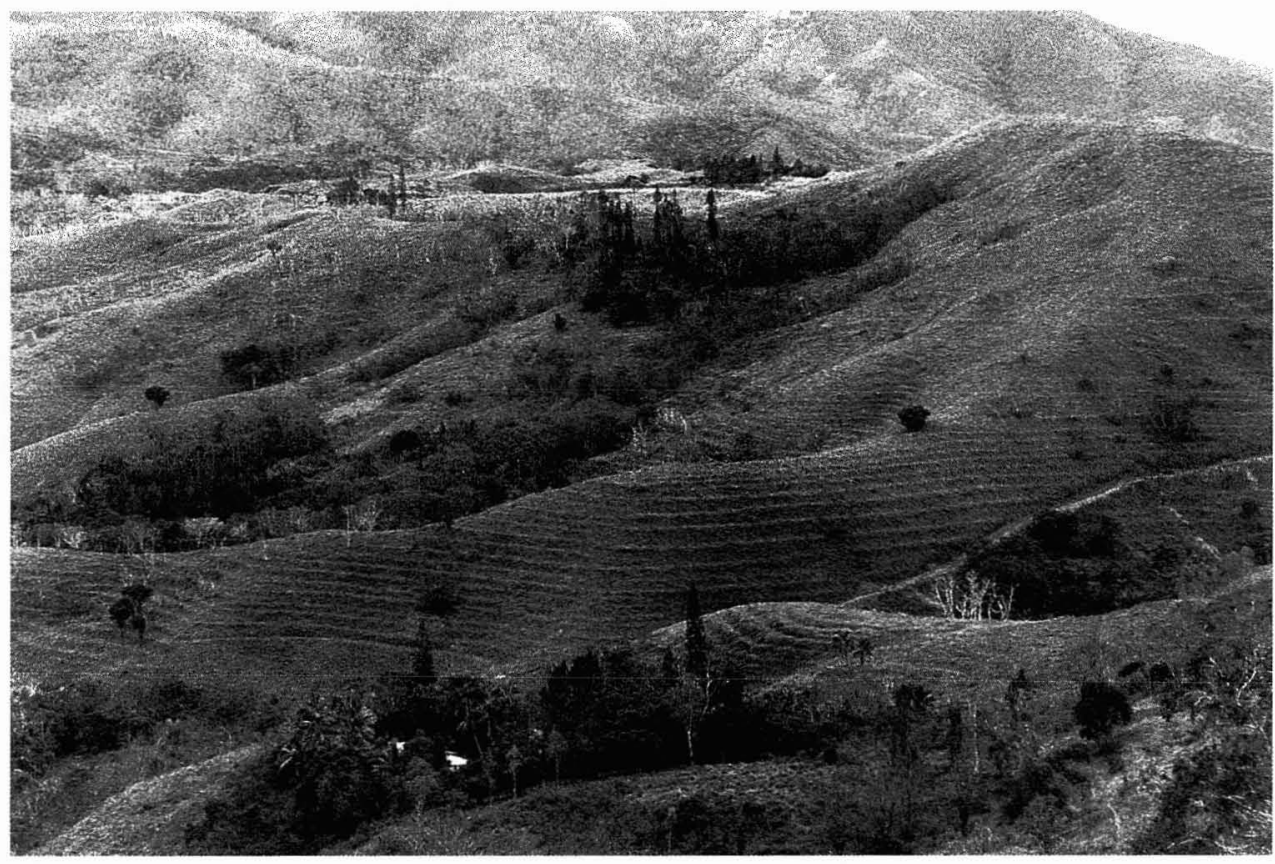

Fig. 4. Abandoned taro pondfield terraces from New Caledonia.

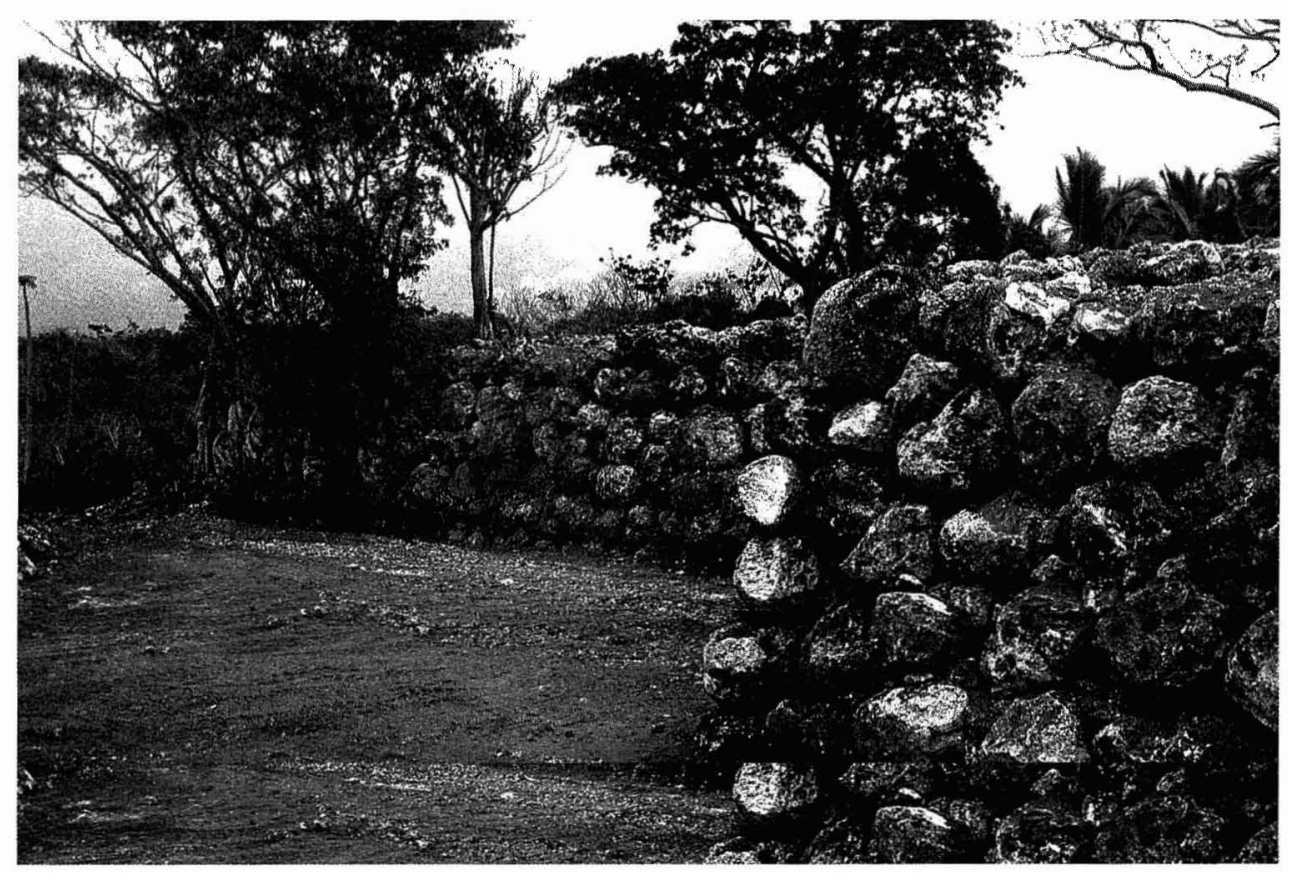

Fig. 5. Example of a megalithic fortification wall on Maré (Loyalty Islands). 


\section{Interaction Spheres}

The final data set that can be taken into account is inter-island exchanges and interactions. For the last millennium of Melanesian prehistory, inter-archipelago long-distance exchange of material objects has been poorly recorded, apart from the Polynesian outliers such as Tikopia (Kirch 1986; Kirch and Yen 1982). But pre-European archipelago-wide interactions have begun to be evidenced in recent research programs, showing a wide diversity of the Melanesian trading traditions, first recorded in Northern Melanesia by ethnographers such as Malinowski (1922). For New Caledonia, we see a wide ranging exchange-system at work between the Grande Terre and the Loyalty Islands, and up into southern Vanuatu, with the circulation of pots, adzes, flakes, and shell ornaments (Sand 1998). Exchange probably also included mats, barkcloth, and women. In the Solomons, complex symbolic processes surrounded the fabrication, use, circulation, and breakage of shell bracelets and ornaments. A regional network of exchanges, related to the overall organization of headhunting, was controlled by the Roviana chiefdom as far as Guadalcanal and Malaita with the construction of large paddling war canoes (Walter and Sheppard, in press). These different interaction processes were not made at a "clan" or "tribe" level, but involved complex chiefdom redistribution strategies, allowing the hereditary chiefs to maintain their prestige and control (Sand 1995).

\section{Some Anthropological Examples of Melanesian Complexity}

A major point of distinction proposed by Sahlins (1963) between the hypothetical political systems of the western Pacific and Polynesia focused on the succession of leadership. In Melanesia, as opposed to Polynesia, leaders were said not to inherit their positions, as leadership changed at each generation through the personal prestige of some members of the community. Attempts to apply this model for individual sectors of the Melanesian region has, significantly, shown its limits. In New Caledonia, parts of Vanuatu, and the Solomons, the chiefs were in fact hereditary over several generations (Guiart 1992). The Big-Man nature of the Siwai society in southern Bougainville Island (Oliver 1955) - used as a type-case for the definition of the "Big-Man" system by Sahlins (1963) - appears on recent evidence to have replaced only about 100 years ago a formerly more hierarchical system with title holders, following population collapse due to the introduction of European diseases (Spriggs 1993:198-199). Even in the New Guinea Highlands, classic Big-Man systems appear to be partly the result of massive political disruption after European contact during the first half of the twentieth century (Golson 1982; Gosden 1999: 103).

All these data on former hereditary Melanesian chieftainships-with their defined hierarchy and social boundaries - suggest that they were as diversified and complex as their Polynesian counterparts (Kirch 1984a). This is not to say that they functioned in precisely the same ways (Sand 2000), but fundamentally highlights that there were in late prehistory more hierarchical systems with chiefdoms in Island Melanesia than most twentieth-century anthropologists recognized. One of the multiple examples that can be used to show the complexity of some of these Melanesian political systems is the existence of a proper "elite language" in 
some chiefdoms (e.g., Lenormand 1990). Such "languages," out of use today in most places, were different from the everyday speech and were reserved for the court of the chief.

Oral traditions in various regions as well as some present-day social behavior, indicates that the "chief" as community symbol was tapu, or sacred (e.g., Gaudin 1999). Commoners were not allowed to approach this elite person, and all sorts of rituals were observed around its person. Objects touched by the chief also became tapu, the rest of his meals had to be buried or disposed of in a special place so that no one might fall ill because of touching these remains. He was also the center of complex relationships with the natural world, and captured turtles (for example) could only be redistributed after presentation to the chief.

\section{DISCUSSION}

What may we conclude from these disparate data? Multiple sources of new information-gathered from different archipelagoes and disciplines-strongly suggest that the idea of a low-status, low-hierarchy Melanesian system as proposed by twentieth-century ethnography, is not supported by the archaeological and historical data. Settlement pattern studies show intensively modified prehistoric landscapes, intensified living and horticultural areas, with complex technical constructions and irrigation systems that could not have functioned within smallscale tribal societies. Ethnohistorical analysis shows for its part a deep transformation of indigenous societies following initial European contact, with massive population collapse after the introduction of foreign diseases. Consequently, the divide between prehistoric Melanesia and Polynesia in sociopolitical terms is far less evident than what anthropologists have classically suggested, but rather is the outcome of complex historical factors. This is not to say, once again, that the prehistoric systems of the two regions were identical. From a re-reading of the anthropological data on the Kanak societies of New Caledonia for example (Sand 1995, 2000), it appears that the central symbol of some former Melanesian chiefdom systems relied on the horticultural calendar. The chief embodied the annual calendar, had to initiate the different phases of planting and harvesting, and had, with his court, a magical relationship with the ancestors.

What is probably the most significant implication, when we compare the two regions, is a fundamental divide in processes of cultural differentiation. From a common Austronesian ancestry derived from the Lapita Cultural Complex of 3000 years ago (Green 1997; Kirch 1997), the populations of Island Melanesia and Western Polynesia diverged along different pathways. In Western Polynesia, a more homogeneous regional pattern seems to have been maintained, leading to a common cultural background for the people who colonized the islands and archipelagoes of East Polynesia in the first millennium A.D. (Kirch 2000; Spriggs and Anderson 1993). In Island Melanesia, in contrast, we see archaeologically a rapid diversification of the founding cultures (Bedford 2000; Sand 1999b), possibly with later cultural input from non-Austronesian groups (Spriggs 1997), leading to the remarkable diversity of Island Melanesian societies.

Significantly, this was a complex and long cultural process, as chronological reconstructions tend to show a general three-phase prehistory of the southwestern Pacific region. As later in the case of East Polynesia, we have in Island Melanesia, 
south of the Solomons, a first settlement period characterized by regular interaction over at least archipelago-wide distances, with occasional inter-archipelago exchange (Sand 2001; Spriggs 1997). As later in East Polynesia, this is followed after about one millennium by the breakdown of most large-scale interactions, each island apparently becoming more isolated (Sand 1995). The final millennium of prehistory in the southwestern Pacific archipelagoes is characterized by redevelopment of intensive interaction spheres (Spriggs 1997; Sand 1998), a new phase not experienced during the shorter chronology of Eastern Polynesia. West Polynesian settlements on Melanesian Islands (Kirch 1984b) are only one part of a much larger and complex regional phenomenon.

One might speculate that this large-scale interaction phase would also have taken place in Eastern Polynesia if Europeans had not intruded in Pacific history, remembering that cultural trajectories have complex dynamics. This can for example be seen when comparing the chronological development of horticultural intensification. Whatever the first settlement date of Eastern Polynesia, one millennium or less after the first Polynesian discovery, the intensification process in East Polynesia was well underway (Kirch 2000). For Island Melanesia, archaeological data seem to suggest that a time period at least twice as long was required to begin to witness intensification over the landscape, with taro pondfield terrace construction commencing late in the first millennium A.D. (Sand 1999a; Spriggs 1981). No satisfactory explanation has been put forward for this difference. One possible explanatory factor is certainly related to environmental settings and the differential size of the islands, but it cannot account for the entire process. Another explanatory factor might be a required phase of environmental adaptations in the western part of Remote Oceania following first Austronesian settlement, preadapting a faster pace of change during the subsequent expansion into East Polynesia a millennium and a half later.

\section{CONCLUSION}

Settled late by Europeans, after in some cases more than a century of irregular contacts and black-birding, leading to the introduction of diseases and population collapse (Rallu 1990; Shineberg 1999), serious ethnographical study of most of the Melanesian islands had to await the turn of the twentieth century. What the ethnographers observed and recorded were profoundly changed indigenous societies, although most of them failed to realize this. As Chris Gosden has recently pointed out (Gosden, in press), what Europeans wanted to see in Melanesia were the remnants of the first and oldest societies, indeed the "savage" part of ancestral European history. The picture of "traditional" Melanesian systems seen through the eyes of anthropologists was, though necessarily biased, keeping alive the idea of the "civilized Polynesians" vs. the "savage (and black) Melanesians" (Boulay 2000). Archaeology is finally demonstrating that former Melanesian societies had achieved a "civilization" in their island environments that no modern economy has been able to match to the present day.

\section{NOTE}

1. This paper is not intended to discuss at length the mechanisms of prehistoric differentiation between Melanesian and Polynesian societies, which have been extensively discussed in different ways during the last decade (e.g., Bradshaw 1997; Pawley 1982; Spriggs 1997; Terrell 1986). 


\section{REFERENCES CITED}

BARRAU, J.

1965 Histoire et préhistoire horticoles de l'Océanie tropicale. Journal de la Société des Océanistes $21: 55-78$.

Beaglehole, J. C.

1974 The Life of Captain James Cook. Stanford, CA: Stanford University Press.

BEDFORD, S.

2000 Pieces of the Vanuatu Puzzle: Archaeology of the North, South and Centre. Unpublished Ph.D. diss., Australian National University, Canberra.

BeLlWOOD, P. S.

1979 Man's Conquest of the Pacific (The Prehistory of Southeast Asia and Oceania). Auckland: Collins Publication Ltd.

Best, S.

1993 At the Hall of the Mountain Kings: Fijian and Samoan fortifications: Comparison and analysis. Journal of the Polynesian Society 101(1):385-447.

\section{Bonnemaison, J.}

1974 Espaces et paysages agraires dans le nord de Nouvelles-Hébrides. L'exemple des îles d'Aoba et de Maewo. Paris: Société des Océanistes.

1984 L'arbre et la pirogue. Paris: Editions de l'ORSTOM.

Boulay, R.

1990 La maison kanak. Collection Architectures traditionnelles. Ed. Parenthèses-ADCKORSTOM.

2000 Cannibales et Vahinés. Nouméa: Editions Grain de Sable.

BRADSHAw, J.

1997 The population kaleidoscope: Another factor in the Melanesian diversity v. Polynesian homogeneity debate. Journal of the Polynesian Society 106(3):222-249.

Burenhult, G.

1994 Les monuments de Pierre du Pacifique Sud, in Le Nouveau Monde et le Pacifique: 165-183. Paris: Editions Bordas.

CoIffier, C.

1988 Traditional Architecture in Vanuatu. Suva: University of the South Pacific.

DOUgLAS, B.

1979 Rank, power, authority: A reassessment of traditional leadership in South Pacific societies. The Journal of Pacific History 14:2-27.

Gaudin, P.

1999 Organisations sociales, in Chroniques du Pays Kanak: 168-193. Nouméa: Planète Mémo.

Godelier, M.

1982 La production des grands hommes. Pouvoir et domination masculine chez les Baruya de NouvelleGuinée. Paris: Fayard.

Goldman, I.

1970 Ancient Polynesian Society. Chicago: University of Chicago Press.

Golson, J.

1982 The Ipomoean revolution revisited: Society of the sweet potato in the upper Wahgi Valley, in Inequality in New Guinea Highland Societies: 109-136, ed. A. Strathern. Cambridge: Cambridge University Press.

Gosden, C.

1999 Anthropology and Archaeology. A Changing Relationship. London and New York: Routledge.

In press Collecting colonialism: material culture and colonialism in Papua New Guinea, in $A$ Pacific Odyssey: Essays in Honour of Jim Specht.

GREen, R. C.

1991 Near and Remote Oceania-disestablishing "Melanesia" in culture history, in Man and a Half: Essays in Pacific Anthropology and Ethnobiology in Honour of Ralph Bulmer: 491-502, ed. A. Pawley. The Polynesia Society.

1997 Linguistic, biological, and cultural origins of the initial inhabitants of Remote Oceania. New Zealand Journal of Archaeology 17:5-27. 
GuiArt, J.

1963 La Chefferie en Mélanésie du Sud. Paris: Institut d'ethnologie, Musée de l'Homme.

1992 Structure de la Chefferie en Mélanésie du Sud. Vol. 1. Paris: Institut d'ethnologie, Musée de l'Homme.

KIRCH, P. V.

1984a The Evolution of the Polynesian Chiefdoms. Cambridge: New Studies in Archaeology, Cambridge University Press.

19846 The Polynesian outliers. Continuity, change, and replacement. Journal of Pacific History 19(4): 224-238.

1985 Feathered Gods and Fishhooks. An Introduction to Hawaiian Archaeology and Prehistory. Honolulu: University of Hawai'i Press.

1986 Exchange systems and inter-island contact in the transformation of an island society: The Tikopia case, in Island Societies: Archaeological Approaches to Evolution and Transformation: 33-41, ed. P. V. Kirch. Cambridge: Cambridge University Press.

1994 The Wet and the Dry: Irrigation and Agricultural Intensification in Polynesia. Chicago: University of Chicago Press.

1997 The Lapita Peoples, Ancestors of the Oceanic World. London: Blackwell.

2000 On the Roads of the Winds. Berkeley: University of California Press.

KIRCH, P. V., AND D. YEN

1982 Tikopia. The Prehistory and Ecology of a Polynesian Outlier. B. P. Bishop Museum Bulletin 238. Honolulu.

LAMBERT, P.

1900 Moeurs et superstitions des néo-calédoniens. Nouvelle Imprimerie Nouméenne.

LEMMONIER, P.

1990 Guerres et Festins. Paix, échanges et compétition dans les Highlands de Nouvelle-Guinée. Paris: Editions de la Maison des Sciences de l'Homme.

Lenormand, M. H.

1990 Le Miny, "Langue des chefs" de l'île de Lifou (Iles Loyauté, Nouvelle-Calédonie). Nouméa: Edipop.

MALINOWSKI, B.

1922 Argonauts of the Western Pacific. London: Routledge and Kegan Paul.

MCELDOWNEY, P. H.

1995 Subsistence intensification in the Late Prehistory of Manus. Unpublished Ph.D. diss., Australian National University, Canberra.

Oliver, D. L.

1955 A Solomon Island Society: Kinship and Leadership among the Siuai of Bougainville. Cambridge: Harvard University Press.

OtTino, P.

1990 Hakao 'hoka: Etude d'une Vallée Marquisienne. Travaux et Documents Microédités 66. Paris: ORSTOM.

PARKe, A. L.

1987 Fijian ranked societies. Traditional accounts and archaeological correlates. Unpublished B.A., Australian National University, Canberra.

PAwley, A.

1982 Rubbish-man, commoner, big-man, chief? Linguistic evidence for hereditary chieftainship in Proto-Oceanic society, in Oceanic Studies: Essays in Honour of Aarne A. Koskinen: 33-52, ed. J. Siikala. Transactions of the Finnish Anthropological Society 11. Helsinki: Finnish Anthropological Society.

PARRY, J. T.

1984 Air photo interpretation of fortified sites: Ring-ditch fortifications in Southern Viti Levu. New Zealand Journal of Archaeology $6: 71-93$.

RaLlu, J.-L.

1990 Les Populations Océaniennes aux XIXe et XXe siècles. Institut National d'Etudes Démographiques. Travaux et Documents, Cahier 128.

SAHLINS, M.

1958 Social Stratification in Polynesia. Seattle: American Ethnological Society.

1963 Poor man, rich man, big-man, chief: Political types in Melanesia and Polynesia. Comparative Studies in Society and History $5: 285-303$. 
SAND, C.

1994 Entre mer et montagne. Inventaire archéologique de la Commune de Païta (Province Sud). Nouméa: Les Cahiers de l'Archéologie en Nouvelle-Calédonie 4.

1995 "Le temps d'avant": Préhistoire de la Nouvelle-Calédonie. Contribution à l'étude des modalités d'adaptation et d'évolution des sociétés océaniennes dans un archipel du Sud de la Mélanésie. Paris: Editions L'Haramattan.

1996 Structural remains as markers of complex societies in Southern Melanesia during prehistory: The case of the monumental forts of Maré Island, New Caledonia, in Indo-Pacific Prehistory: The Chiang Mai Papers: 37-44, ed. I. C. Glover and P. Bellwood. Canberra: Bulletin of the Indo-Pacific Prehistory Association 15.

1997 Variété de l'habitat ancien en Nouvelle-Calédonie: Étude de cas sur des vestiges archéologiques du Centre-Nord de la Grande Terre. Journal de la Société des Océanistes 104(1):39-66.

1998 Recent archaeological research in the Loyalty Islands of New Caledonia. Asian Perspectives 37(2): 194-223.

1999a From the swamp to the terrace: Intensification of the horticultural practices in New Caledonia from first settlement to European contact, in The Prehistory of Food: 252-269, ed. C. Gosden and J. Hather. One World Archaeology Series.

$1999 b$ Lapita and non-Lapita ware during New Caledonia's first millennium of Austronesian settlement, in The Western Pacific, 5000 to 2000 BP: Colonisations and Transformations: 139159, ed. J. C. Galipaud and J. Lilley. IRD.

2000 Reconstructing "traditional" Kanak society in New Caledonia: The role of archaeology in the study of European contact, in The Archaeology of Difference: 51-78, ed. R. Torrence and A. Clarke. One World Archaeology Series 38.

2001 Evolutions in the Lapita Cultural Complex: A view from the Southern Lapita Province. Archaeology in Oceania.

Sheppard, P., R. Walter, and T. Nagaoka

2000 The archaeology of head-hunting in Roviana Lagoon. Journal of the Polynesian Society 109(1):9-37.

SHINEBERG, D.

1999 The People Trade: Pacific Laborers and New Caledonia 1865-1930. Pacific Islands Monograph 16. Honolulu: University of Hawai'i Press.

SinOTO, Y.

1996 Mata'ire'a Hill, Huahine: A unique prehistoric settlement, and a hypothetical sequence of marae development in the Society Islands, in Oceanic Culture History: Essays in Honour of Roger Green: 541-553, ed. J. Davidson, G. Irwin, F. Leach, A. Pawley, and D. Brown. Dunedin: New Zealand Journal of Archaeology Special Edition.

SPRIGGS, M.J.T.

1981 Vegetable Kingdoms: Taro Irrigation and Pacific Prehistory. Unpublished Ph.D. diss., Australian National University, Canberra.

1993 Island Melanesia. The last 10,000 years, in A Community of Culture. The People and Prehistory of the Pacific: 187-217, ed. M. Spriggs, D. Yen, W. Ambrose, R. Jones, A. Thorne, and A. Andrews. Occasional Papers in Prehistory 21. Canberra: ANU Press.

1997 The Island Melanesians. Oxford: Blackwell.

Spriggs, M.J.T., AND A. ANDERSON

1993 Late colonisation of East Polynesia. Antiquity 67:200-217.

Terrell, J.

1986 Prehistory in the Pacific Islands. Cambridge: Cambridge University Press.

THомаs, N.

1989 The force of ethnology: Origins and significance of the Melanesia/Polynesia division. Current Anthropology 30:27-41.

1997 In Oceania: Visions, Artifacts, Histories. Durham: Duke University Press.

Walter, R., AND P. ShePpard

In press Nusa Roviana. The archaeology of a Melanesian chiefdom. Journal of Field Archaeology.

\section{ABSTRACT}

The late prehistoric period is crucial to the study of anthropology, as the area of Island Melanesia has provided the world with one of its great anthropological 
stereotypes, the "Big Man" society. This was developed by Sahlins (1963) on the basis of Oliver's (1955) ethnography of the Siwai of southern Bougainville as observed during the late 1930s. It has led to a gross ethnographic oversimplification of Melanesia as having Big Man societies, contrasted with Polynesia having chiefly societies. Where chiefs were found in Melanesia, their presence has often been interpreted as a cultural borrowing under Polynesian influence (Spriggs 1993:198). Keywords: Melanesia; Polynesia; Big Man society; Polynesian chiefdom. 